\title{
O JUDICIÁRIO BRASILEIRO COMO SUPEREGO DA SOCIEDADE: UMA CRÍTICA SOBRE A USURPAÇÃO DA COMPREENSÃO DOS VALORES DE UMA SOCIEDADE
}

\section{Elisa Helena Lesqueves Galante}

Doutoranda em Direitos e Garantias Constitucionais Fundamentais (FDV); Mestre em Direito/ Políticas Públicas e Processo (FDC); membro do Grupo de Pesquisa "Estado, Democracia Constitucional e Direitos Fundamentais" (FDV); Professora Titular da Faculdade de Direito de Cachoeiro de Itapemirim (FDCI); Procuradora Municipal e Advogada; Email: elisahlgalante@gmail.com

Adriano Sant'Ana Pedra

Doutor em Direito Constitucional (Pontifícia Universidade Católica de São Paulo PUC/SP); Mestre em Direitos e Garantias Fundamentais (Faculdade de Direito de Vitória - FDV); Professor do Curso de Direito e do Programa de Pós-Graduação Stricto Sensu (Mestrado e Doutorado) em Direitos e Garantias Fundamentais da Faculdade de Direito de Vitória (FDV); Procurador Federal (Advocacia-Geral da União); Membro da Associação Internacional de Direito Constitucional (IACL) e da Associação Mundial de Justiça Constitucional (AMJC); E-mail: adrianopedra@fdv.br

\section{Resumo}

O artigo reflete sobre a atuaçáo do Poder Judiciário no paradigma do Estado Democrático de Direito objetivando identificar, em especial, as consequências da utilização pelo Judiciário brasileiro da "jurisprudência de valores", de Robert Alexy. Para a reflexão, utilizase a compreensão da socióloga alemã Ingeborg Maus que alertou sobre o perigo de o Poder Judiciário, em especial, o Tribunal Federal Constitucional alemão, definir todos os valores de uma sociedade e, como implicaçáo, abarcar o "superego da sociedade". Para a compreensão do conceito de "superego", apresenta a estrutura do indivíduo construída por Sigmund Freud, bem como a "sociedade órfâ" que emerge de sua construção psicanalítica e sua relação com a atuação do Poder Judiciário neste novo paradigma político e hermenêutico.

\section{Palavras-chave}

Poder Judiciário; Superego; Freud; Censor Moral; Democracia.

\section{Resumen}

El artículo reflexiona sobre el papel del poder judicial en un Estado democrático con el objetivo de identificar, en particular, las consecuencias de la utilización de la "jurisprudencia 
de valores", de Robert Alexy, por la justicia brasileña. Para entender, se utiliza el sociólogo alemán Ingeborg Maus, quien advirtió sobre el peligro del poder judicial, en particular, el Tribunal Constitucional Federal alemán, establecer todos los valores de una sociedad y, como consecuencia, abarcar el "superego de la sociedad". Para entender el concepto de "superego", presenta la estructura del individuo construido por Sigmund Freud, y la "sociedad huérfana” que emerge de su construcción psicoanalítica y su relación con el desempeño de la judicatura en este nuevo paradigma político y hermenéutico.

\section{Palabras clave}

Poder Judicial; Superego; Freud; Censor Moral; Democracia.

\section{Introdução}

Este estudo objetiva examinar o papel do Poder Judiciário no paradigma do Estado Democrático de Direito.

Como base teórica, utilizar-se-á a reflexão publicada em 1989 pela socióloga alemã Ingeborg Maus, intitulada "Judiciário como superego da sociedade: o papel da atividade jurisprudencial na 'sociedade órfä"'. A autora, utilizando-se inicialmente da psicologia freudiana, faz uma critica à "jurisprudência de valores” adotada pelo Judiciário alemão, objetivando mostrar o perigo da atuação do Tribunal Federal Constitucional (TFC) em substituição ao Parlamento ao construir os valores da sociedade alemã.

Serão expostos, sob esse prisma, as bases estruturais da personalidade do indivíduo introduzida por Freud: o id, o ego e o superego, destacando a compreensão do que seja o "superego" e o seu papel na formação do indivíduo como membro de uma sociedade.

Por fim, assumindo a mesma linha de argumentação de Ingeborg Maus, propóe-se um olhar mais acurado para a adoção da "jurisprudência de valores" vestida pelo Judiciário alemão, que tem amparado a atuação do Poder Judiciário brasileiro, contribuindo para o processo de reflexão sobre o perigo que a nossa jovem democracia pode enfrentar.

\section{0 Superego como o Censor Moral para a Busca da Perfeição do Indivíduo e da Sociedade na qual Integra}

O modelo freudiano clássico estruturou a personalidade do indivíduo em três estruturas: o id, o ego e o superego. Para mostrar a construção da personalidade do sujeito, Freud a simbolizou na figura de um iceberg, no qual o id é a parte submersa e mais profunda, que identifica o inconsciente e corresponde à parte mais primitiva, instintiva e menos acessível da personalidade. Segundo Freud (1996a, p. 74) “[...] o id não conhece nenhum 
julgamento de valores: não conhece o bem, nem o mal, nem moralidade”. Por sua vez, o ego é a parte emersa do iceberg, a porção consciente que representa a racionalidade e serve como mediador entre o id e as circunstâncias do mundo externo. A terceira estrutura, criada num momento posterior, a qual Freud denominou de superego, é identificada como a porção de "pré-consciência” (FREUD, 1975, p. 103) e também de inconsciência, localizada na parte submersa mais próxima à linha do horizonte, entre o id e o ego, constituindo-se como o aspecto moral e ético internalizados. Para Freud (1975, p. 75):

No curso do desenvolvimento de um indivíduo, uma parte das forças inibidoras do mundo externo é internalizada e constrói-se no ego uma instância que confronta o restante do ego num sentido observador, crítico e proibidor. Chamamos essa nova instância de superego.

Freud (1996c, p. 67) descreveu o superego como sendo o defensor da luta em busca da perfeição. Portanto, o superego é como um freio moral, melhor descrito, como um censor moral para alcançar a perfeição do sujeito.

No edifício científico de Freud, o pai (em sentido lato sensu) é a primeira figura pela qual esse superego é formado. É na figura do pai que o censo moral do filho começa a ser erigido, transmitindo para o filho, de forma totalmente inconsciente, um modelo de ser cultural. Mas, na formação do indivíduo, após os pais, surgem novos modelos, inicialmente os professores, depois as figuras importantes dos mais variado ambientes, como artistas, jogadores de futebol, donos dos morros, traficantes, etc. Enfim, todos aqueles que têm uma representação externada na sociedade. É como esclarece o Pai da Psicanálise:

Esta influência parental, naturalmente, inclui em sua operação não somente a personalidade dos próprios pais, mas também a família, as tradiçôes raciais e nacionais por eles transmitidas, bem como as exigências do milieu social imediato que representam. Da mesma maneira, o superego, ao longo do desenvolvimento de um indivíduo, recebe contribuiçôes de sucessores e substitutos posteriores aos pais, tais como professores e modelos, na vida pública, de ideais sociais admirados (FREUD, 1975, p. 93).

Nos estudos freudianos, o movimento de ampliação do indivíduo identificará nas instituiçóes outros novos mecanismos de formação do superego: o clã e seu totem, o judeu e seu Moisés, a Bíblia e seu Deus, a Igreja e seu Papa, o Estado e seu Rei ou Presidente, etc.

É até fácil imaginar, ou mesmo identificar, que o indivíduo tenha uma reverência religiosa com quem quer que esteja funcionando como modelo para o seu superego, pois esse alguém o está constituindo como indivíduo. Ele depende desse alguém para ser construído como pessoa humana, ou seja, esse alguém é sentido quase como um Deus criador, afinal, ele está edificando sua personalidade.

É dessa dinâmica que Ingeborg Maus se utiliza para dizer que, depois da Igreja, do Legislativo e do Executivo, o Judiciário se constitui como o novo superego da sociedade. 
Ingeborg Maus (2000, p. 184) registra sua compreensão a partir do escrito de Herbert Marcuse, sociólogo e filósofo alemão naturalizado norte-americano que, em 1960, constatava o "envelhecimento da psicanálise" ou, como esclarece, o "envelhecimento de seu objeto", a partir da compreensão de que a figura do pai não era mais determinante para a formaçáo do indivíduo que estaria muito mais determinado pelas diretrizes sociais.

Entretanto, para Freud, o Pai da Psicanálise, em "Totem e Tabu"1 (1996a), a orfandade tem sua origem no assassinato do pai originário do clá que se encontra desamparado e, para substituir a nostalgia latente, surge a religiáo com o Pai benevolente, o "Deus" onipotente, onipresente e onisciente. Desse modo, para Freud, o pai como sujeito fraterno só é fundamento para a formação do indivíduo nos primeiros anos de vida, sendo posteriormente substituído pelas representaçóes sociais. Naquele estudo original, a "religiosidade" e seu "Deus" foram elevados ao pai social, exercendo a função paterna. Em estudo posterior - "O futuro de uma ilusão" - Freud (1996b, p. 42) concluiu que a religião é a "[...] neurose obsessiva universal da humanidade".

Esse fundamento é identificado pela também socióloga Marilena Chauí em sua obra editada pela passagem dos 500 anos do Brasil - "Brasil: mito fundador e sociedade autoritária" (2000) -, na qual esclarece que os brasileiros não tinham muito o que comemorar. E, na mão contrária à saudação, faz sua crítica a partir dos estereótipos produzidos pelo pensamento social, por meio da literatura, dos escritos científicos, dos discursos políticos, entre outros, que formam "uma representação de Brasil para os brasileiros".

Dentre os exemplos traçados por Chauí, destaca-se o descrito no terceiro capítulo - o verde-amarelismo - particularmente o do século XX, inicialmente alimentado na Era Vargas; mas, muito em especial, o gerado na Copa do Mundo de 1970, quando o superego da sociedade brasileira está centrado no Poder Executivo, e o Brasil, em pleno núcleo duro da ditadura, se verde-amarelou no mito de uma "idéia de consciência nacional". Ou seja, por necessidade das pessoas de "algo absoluto", elas vão, aos poucos, empurrando a instituição para que funcione como modelo de superego, e esta vai, também aos poucos, se assenhoreando desse papel.

É nessa mesma linha o estudo apresentado por Maus e, voltando à origem dos seus argumentos, é muito importante refletir que, ao encarnar o superego, o Poder Judiciário infantiliza a sociedade. Forma-se como um conluio. A sociedade precisa e o Judiciário quer. A sociedade acomoda-se e espera que o Judiciário diga o que é bom e o que é ruim em todos os sentidos. Ou seja, ao projetar no Judiciário a instância moral, a sociedade para de crescer e se infantiliza. É semelhante ao que ocorre com a criança que se ampara no pai e nunca "cresce". Para a psicanálise, o ideal é que a criança, para sua evolução, vá

1 “Totem e tabu”, redigida entre 1912 e 1913, é a primeira obra que Freud dedica à psicologia coletiva. 
relativizando a palavra do pai e, a partir de suas próprias compreensóes, escape da figura paterna, reflita e se constitua como indivíduo. Ao contrário, o indivíduo que fica eternamente sob o domínio do pai e que não o questiona se manterá eternamente criança.

É isso que, na crítica freudiana, é a infantilização do indivíduo e provoca uma radical limitação de sua capacidade de reflexão. É, enfim, o que Freud denominou de neurose obsessiva da humanidade. E é nesse contexto que, na medida em que o Poder Judiciário usurpa esse lugar das instituiçóes que o antecederam como superego de uma sociedade, traz para si também a mesma crítica e, parafraseando o Pai da Psicanálise, passa, então, o Poder Judiciário a ser a neurose obsessiva da sociedade.

\section{O Princípio Constitucional da Separação de Poderes no Paradigma do Es- tado Democrático de Direito}

Inspirada na obra de Montesquieu (“O espírito das leis”, 1748), ${ }^{2}$ a separação dos poderes foi formalmente firmada como princípio fundamental na Declaração Universal dos Direitos do Homem e do Cidadão (1789). Consagrou-se, portanto, que o exercício das funções estatais deve ser dividido entre órgãos independentes e autônomos, pois, segundo Montesquieu, não haveria liberdade se o poder estivesse concentrado na mão de um indivíduo, pois, sendo ilimitado, tenderia a abusar.

Quando, na mesma pessoa ou no mesmo corpo de magistratura, o poder Legislativo está reunido ao poder Executivo, não existe liberdade; porque se pode temer que o mesmo monarca ou o mesmo senado crie leis tirânicas para executá-las tiranicamente. Tampouco existe liberdade se o poder de julgar não for separado do poder Legislativo e do Executivo. Se estivesse unido ao poder Legislativo, o poder sobre a vida e a liberdade dos cidadãos seria arbitrário, pois o juiz seria legislador. Se estivesse unido ao poder Executivo, o juiz poderia ter a força de um opressor.

Tudo estaria perdido se o mesmo homem, ou o mesmo corpo dos principais, ou dos nobres, ou do povo exercesse os três poderes: o de fazer as leis, o de executar as resoluçóes públicas e o de julgar os crimes ou as querelas entre os particulares (MONTESQUIEU, 2000, p. 172).

Há de ser enfatizado que, historicamente, o Princípio da Separação dos Poderes nunca estancou uma divisão inexorável, visto que os Poderes constituídos, além de suas funçôes típicas (legislativa, judicante e administrativa), também acoplavam funçôes atípicas (legislativa, judicante e administrativa). Dentre elas, destaca-se a função administrativa

2 Outros autores precederam na formação do princípio da separação dos poderes, como John Locke (Segundo tratado sobre o governo. São Paulo: Martin Claret, 2006, p. 92 e 109) e Jean-Jacques Rosseau (Textos filosóficos, Tradução Lucia Pereira de Souza. Rio de Janeiro: Paz e Terra, 2002, p. 7), embora considerassem o Legislativo superior, o que diferenciou as liçóes de Montesquieu. 
que é exercida rotineiramente por todos os órgáos independentes. Fica, entấo, a cargo do sistema de checks and balances a contribuição para garantir o equilíbrio e a independência.

No Estado de Direito, fundado sob o Princípio da Separação dos Poderes, coube ao Poder Legislativo o papel fundamental na concretização do Direito. No entanto, “[...] o ideal da estrita separação dos poderes teve como consequência um Judiciário perigosamente débil e confinado, em essência, aos conflitos privados" (CAPPELLETTI, 1993, p. 53). Mesmo assim é irrefutável que o papel do Princípio da Separação dos Poderes na formação do Estado Nacional foi fundamental para assegurar o não retorno ao Absolutismo. Isso, contudo, como leciona Coura (2009, p. 160):

[...] não significa que a noção de separação dos poderes do paradigma Liberal seja tomada, enquanto descrição simplificadora de um ponto de partida histórico, como um valor em si mesmo, pois o atual contexto histórico requer outras respostas, para além daquelas que alcançarem êxito no passado.

É nesse contexto que, após a derrocada do paradigma do Estado de Direito, o novel Estado do Bem-Estar Social exigiu do Poder Judiciário um papel mais ativo para a satisfação dos ideais sociais, bem como o distanciamento da atuação normativo-positivista da jurisdiçáo liberal, afastando-se do paradigma do juiz "boca da lei" para uma nova concepção de juiz.

Habermas (2003, p. 125) denominou o processo de "mudança social do direito", esclarecendo que, inicialmente, “[...] uma nova compreensão instrumental do direito, referida as ideias de justiça do Estado social vinha sobrepor-se ao modelo do direito liberal e, no final, substituí-lo”. Seguindo o traço histórico adveio, após a Segunda Grande Guerra Mundial, um novo desenho, pois os fatos e os atos que antecederam e decorreram impuseram uma nova configuração política: o Estado Democrático de Direito. Esse novo paradigma político centrou seus pilares básicos na dignidade da pessoa humana, no acesso à justiça e na democracia participativa. Passa o Direito, então, como destaca Streck (2009, p. 2), no "Estado Democrático (Social) de Direito", a ser um instrumento de realização de políticas públicas e também do imenso catálogo de direitos fundamentais sociais. Esclarece ainda o autor:

[...] é preciso compreender que nessa quadra da história, o direito assume um caráter hermenêutico, tendo como conseqüência um efetivo crescimento no grau de deslocamento do pólo de tensão entre os poderes do Estado em direção à jurisdição (constitucional), pela impossibilidade de o legislativo (a lei) poder antever todas as hipóteses de aplicação. (STRECK, 2009, p. 1)

É, portanto, a partir do paradigma do Estado Democrático de Direito que se reconhece que a separação dos poderes deve ser enxergada com um novo olhar, de forma a 
compreender que a Jurisdição Constitucional é igualmente um instrumento para a efetivação dos direitos fundamentais.

Em outras palavras, enquanto o Legislativo predominou no Estado Liberal e o Executivo no Estado Social, agora seria a vez do Judiciário (CRUZ, 2008, p. 13). Mas essa supremacia não pode ser compreendida com o "extremismo" - que ora se desenvolve no Brasil na atuação do Poder Judiciário a partir da "ponderação à brasileira”, que será tratado no próximo tópico.

As atuações dos Poderes constituídos são limitadas pelas normas, em especial, pela Constituição. Nos últimos anos, as balizas que definem a competência do Poder Executivo e do Poder Legislativo têm sido objeto de substancial fiscalização. No Poder Judiciário, o sistema de controle tem se preocupado com a celeridade processual, buscando garanti-la pela criação de metas numéricas para julgamento dos processos. A partir de todo o contexto, indaga-se: no novo Estado Democrático de Direito, qual é o limite substancial da atuação do Poder Judiciário?

O primeiro capítulo começou a ser redigido na Constituinte, quando ao Supremo Tribunal Federal foi atribuída à função de guardião da Constituição. Realça Gisele Cittadino (2000, p. 62) que essa função “[...] remete necessariamente ao caráter político que assume o Supremo Tribunal Federal no novo texto constitucional”. E complementa:

Afinal a função de declarar o sentido e o alcance da regras jurídicas, especialmente na função jurisdicional de tutela da Constituição, traduz uma ação política ou, pelo menos, uma ação de inexorável repercussão política.

É inegável, portanto, que, na qualidade de último interprete da Constituição, o Poder Judiciário tenha um papel preeminente. Tal como se espera, “[...] que o juiz, frente à inexistência normativa, resolva o caso concreto, garantindo o direito daquele que o invoca” (CITADINO, 2000, p. 67-69). Em síntese, na lição de Cittadino, esse foi o produto do ideal dos constitucionalistas "comunitários" brasileiros: uma justiça distributiva.

\section{A "Jurisprudência de Valores" e a Crítica à "Ponderação à Brasileira": 0 Arbítrio Livre do Juiz}

As discussóes acerca da tutela jurisdicional, no Estado Democrático de Direito, nem de perto se encerram com o reconhecimento da existência de um "[...] ordenamento jurídico integrado por princípios” (COURA, 2009, p. 74). A teoria da ponderação de Robert Alexy, em especial no modus operandi adotado pelo Poder Judiciário brasileiro, conclamou reflexões, desta feita, quanto à (in)certeza da interpretação e à aplicação do Direito. A reflexão é fundamental para evitar que o juiz tenha a força de um opressor, como previu Montesquieu há séculos, em especial quando assume o papel de legislador. 
É de bom alvitre lembrar que o normativismo jurídico cumpriu uma importante função social, tendo mudado a face do Direito, substituindo-a pela segurança da lei. Nesse contexto, Hans Kelsen trouxe uma elevada contribuição, quando foi capaz de elevar a ciência jurídica ao cume do sentido lógico e, como leciona Coura (2009, p. 59), por meio de um ordenamento jurídico "[...] reduzido a um conjunto fechado e hierarquizado de regras, normas aplicáveis à maneira 'tudo ou nada', por serem capazes de regular suas próprias condiçóes de aplicação". Concebeu Kelsen o projeto da "teoria pura do direito". No entanto, anteriormente (na primavera de 1872), mesmo num discurso positivista, já havia alertado Rudolf Von Ihering (1990, p. 1) que “[...] o direito não é uma pura teoria, mas uma força viva”.

A crise do modelo fechado de regras se resume ao fato de que "[...] a tarefa de julgar necessariamente requer um juízo de adequabilidade, que represente uma mediação entre a norma geral e abstrata e os casos concretos que se apresentem" (COURA, 2009, p. 67). Apoia-se Alexandre Coura na tese de Ronald Dworkin de "defender uma teoria melhor" na qual o juiz tem o dever de desvelar quais são os direitos das partes também nos "casos difíceis", ou seja, naqueles em que a pretensão não pode ser submetida a uma regra clara do Direito, pois cada caso concreto se apresenta "[...] único, irrepetível e também passível de distintas atribuiçóes de sentido, que variam segundo este ou aquele paradigma” (COURA, 2009, p. 67).

Neste texto, não serão abordadas as distinções entre regras e princípios ou mesmo sobre a aplicação das regras, mas, em especial, a compreensão da perspectiva principiológica do Direito e a adoção da interpretação dos princípios como um catálogo "extraordinariamente" aberto conforme vem sendo adotado no Brasil, a partir de uma compreensão à brasileira da teoria de Robert Alexy.

Relevante contribuição para o estudo dos princípios foi o diálogo entre o americano Ronald Dworkin e o alemão Robert Alexy, pois ambos sustentam a importância do princípio para a compreensão do Direito e acordam na premissa de que tanto a regra como o princípio é espécie do gênero norma.

Numa ordem cronológica, lembramos a construção científica de Ronald Dworkin, proposta na obra "Levando os direitos a sério", editada em 1977, que gerou impacto na ciência jurídica pela crítica ao positivismo, utilizando como mira "O conceito de direito" de Hart, e que, posteriormente, foi maturada ao editar "O império do direito" em 1986. Dworkin defende a inexistência de discricionariedade judicial em casos difíceis, em contraponto a Hart que defendia que o juiz possuiria uma margem de liberdade para alcançar a melhor decisão, quando o Direito não fornecesse a resposta, pois, para Hart, este se constituía exclusivamente de regras jurídicas. Em resumo, para Dworkin, o ordenamento jurídico é formado por um conjunto de regras e princípios e: 
A diferença entre princípios jurídicos e regras é de natureza lógica. Os dois conjuntos de padrôes apontam para decisôes particulares acerca da obrigação jurídica em circunstâncias específicas, mas distinguem-se quanto à natureza da orientaçáo que oferecem. As regras são aplicáveis à maneira tudo ou nada. Dados os fatos que uma regra estipula, entâo ou a regra é válida, e neste caso a resposta que ela fornece deve ser aceita, ou não é válida, e neste caso em nada contribui para a decisão (DWORKIN, 2007, p. 39).

Esclarece Dworkin que os princípios possuem dimensão que as regras não têm. $\mathrm{O}$ princípio se apresenta como a "dimensão de peso e importância" e, quando estes se entrecruzam:

[...], aquele que vai resolver o conflito tem de levar em conta a força relativa de cada um. Esta não pode ser, por certo, uma mensuraçáo exata e o julgamento que determina que um princípio ou uma política particular é mais importante que outra freqüentemente será objeto de controvérsia (DWORKIN, 2007, p. 39).

Enfim, para Dworkin, o Direito deve ser compreendido como uma "questáo de princípios" para a solução do hard case, mas mantido o seu caráter deontológico (deverser). Como já relatado, Robert Alexy (1993, p. 11) anui que "[...] tanto las reglas como los principios pueden concerbirse como normas". ${ }^{3}$ No entanto, para Alexy, os princípios são "mandados de otimização" e

O ponto decisivo na distinção entre regras e princípios é que princípios são normas que ordenam que algo seja realizado na maior medida possível dentro das possibilidades jurídicas e fáticas existentes. Princípios são, por conseguinte, mandamentos de otimização, que são caracterizados por poderem ser satisfeitos em graus variados e pelo fato de que a media devida de sua satisfaçáo não depende somente das possibilidades fáticas, mas também das possibilidades jurídicas. O âmbito das possibilidades jurídicas é determinado pelos princípios e regras colidentes (ALEXY, 2006, p. 90)

Alexy propóe a técnica da "ponderação de interesses" ou "ponderação de valores" e afiança que não há superioridade formal de um princípio sobre o outro:

$\mathrm{Na}$ verdade o que ocorre é que um dos princípios tem procedência em face do outro sob determinadas condiçóes. Sob outras condições a questáo de precedência pode ser resolvida de forma oposta. Isso é o que se quer dizer quando afirma que, nos casos concretos, os princípios têm pesos diferentes e que os princípios com o maior peso têm precedência.

3 Tanto as regras como os princípios podem ser concebidos como normas (tradução nossa). 
Conflitos entre regras ocorrem na dimensão da validade, enquanto as colisôes entre princípios - visto que só princípios válidos podem colidir - ocorrem, para além dessa dimensão, na dimensão de peso (ALEXY, 2006, p. 93-94).

Neste caminho, no início deste século, no mundo, como consequência da atuação do Poder Judiciário, em especial na Alemanha, o Supremo Tribunal Federal brasileiro passa a rever a sua jurisprudência com base nesta nova compreensáo, segundo a qual o raciocínio jurídico deve ser compreendido como uma "ponderação de valores", em que os princípios constitucionais passam a ser tratados como "comandos otimizáveis", aplicáveis num comando gradual mediante a utilização de "regra de prioridade" e do "princípio da proporcionalidade", com suas três cabeças: adequação, necessidade e estrita proporcionalidade.

Nesse balanço, Marcelo Cattoni de Oliveira (2005, p. 258-259) ressalta que a mudança de paradigma no Brasil foi inicialmente impregnada de uma resistência natural porque envolve reconhecer "[...] o caráter finito, falível e precário da condição humana” e lembra que, no julgamento do Mandado de Injunção no 107 (1990), o Supremo Tribunal Federal rechaçou o novo paradigma principiológico do ordenamento jurídico, mantendo-se apegado ao paradigma positivista e, naquele caso inaugural, limitou-se a declarar a omissão normativa existente, sem apreciar o direito violado.

Segundo Cattoni (2005, p. 260), o julgado consagrou “[...] não somente uma interpretação inadequada da separação dos poderes, como, em razão de uma compreensão da norma jurídica reduzida à regra, não reconheceu o caráter principiológico do ordenamento". Cittadino (2000, p 69-71) relata que a decisão proferida no MI no 107 ocasionou uma insatisfação generalizada, devidamente retratada nas publicaçóes em jornais de grande circulaçáo nacional - transcritas pela autora -, ressaltando que a mudança de paradigma nas decisóes seguintes (MI no 283/91 e 232/92) parece ter sido fruto da resistência ao constitucionalismo "comunitário".

É nesse contexto que, no limiar do século, o STF transpóe o modelo positivista e ruma ao novo paradigma principiológico, passando, então, a abarcar que o

[...] raciocínio jurídico deve ser compreendido como uma 'ponderação de valores', em que os princípios constitucionais passam a ser tratados, seguindo a tradição da jurisprudência dos valores na Alemanha, como 'comandos otimizáveis', que colidem entre si para reger um caso concreto (CATTONI DE OLIVEIRA, 2005, p. 260-261).

Coura (2009, p. 77-78) esclarece que, no Brasil, é possível identificar várias decisóes judiciais que manifestam o reconhecimento da "[...] ponderação de bens e interesses" e da aplicação do 'princípio da proporcionalidade', empregado como 'método' ou 'critério' 
jurisdicional de ponderação, buscando-se, assim, 'racionalizar' a prática desta e 'justificar' os juízos que delas decorram". ${ }^{4}$

O julgamento do "caso Ellwanger", também alcunhado de "habeas corpus do racismo", 5 foi emblemático por vários aspectos e já analisado por juristas como Alexandre de Castro Coura, José Emílio Medauar Ommati e Marcelo Andrade Cattoni de Oliveira, dentre outros aqui não citados, em que se teceu a teia fundamental da adoção da "ponderação de valores" pelo Judiciário brasileiro, ao apreciar, como pano de fundo, a colisão dos princípios da liberdade de expressão e da dignidade da pessoa humana. Concomitantemente, abriu a "caixa de pandora" e, com o que dela emergiu (e vem emergindo), instauraram-se o debate e novas acirradas críticas.

Para Streck (2009, p. 77), essa atuação marca um acentuado protagonismo do Poder Judiciário brasileiro no contexto político atual, produto do "ativismo judicial”, e também é " [...] duramente criticada por Habermas que a enquadrará como uma postura do poder judiciário que coloniza o espaço público e impede a tomada de decisóes pela via democrática”.

Habermas (1998, p. 318), em crítica à construção cientifica de Robert Alexy, afirma que:

Os que pretendem diluir a constituição numa ordem concreta de valores desconhecem o caráter jurídico específico; enquanto normas do direito, os direitos fundamentais, como também as regras morais, são formados segundo o modelo de normas de ação obrigatórias - e não segundo o modelo de bens atraentes.

No mesmo sentido, retrata Cruz (2008, p. 149):

Para Habermas, assim como para parcela notável da doutrina comparada, a ponderação de valores não consegue se ver livre de uma irracionalidade metodológica e de um decisionismo que são capazes de transformar a atividade jurisdicional em Poder constituinte originário.

Coura (2009, p. 166), também acompanhando a base teórica habermasiana, alerta que "[...] a atividade jurisdicional orientada por valores desconsidera a distinção entre aplicação e criação do direito, contemplando o 'status' de uma legislação concorrente". E, por certo, viola o Estado Democrático de Direito que pretendemos.

4 A partir de sua experiência em grupo de pesquisa na Faculdade de Direito da UFMG, desde 2002, supervisionado pelos doutores Menelick de Carvalho Neto e Marcelo Andrade Cattoni de Oliveira.

5 Trata-se do HC 82.424/RS, julgado em 17 de setembro de 2003, no qual foram apreciadas a prática e crime de racismo por Siegfried Ellwanguer por ter, na qualidade de escritor e sócio da empresa "REVISÃO EDITORA LTDA.", editado, distribuído e vendido ao público obras antissemitas de sua autoria e de autoria de autores nacionais e estrangeiros. 
Tal como retrata Habermas (1997, p. 320), a “[...] 'jurisprudência de valores' levanta realmente o problema da legitimidade, que Maus e Böckenförd analisam, tomando como referência a prática de decisão do Tribunal Constitucional Federal”. Esclarece Habermas que o modelo de concretização coloca a jurisprudência constitucional numa situação de "legislação concorrente".

A transformação da Constituição em uma "ordem de valores" confere às determinações constitucionais individuais (por meio da "abertura" de suas formulações) uma imprecisão tal que é capaz de suprir e ampliar voluntaristicamente os princípios constitucionais positivados (MAUS, 2000, p. 200).

A crítica que Ingeborg Maus (2000, p. 192) fez à “jurisprudência de valores” adotada pelo Judiciário alemáo, objetivando alertar para o perigo da atuação do Tribunal Federal Constitucional "[...] como verdadeiro parlamento ou última instância da definição de todos os valores de uma sociedade", viajou por todo o mundo e, apesar de ter sido produzida no ano de 1989, encontra-se tão atual como naquela data.

Para Maus, essa entrega de "auto-representação da Justiça como instância moral" confere-lhe o cabedal, ou seja, o poder de ser o "superego da sociedade", pois, como esclarecido no primeiro capítulo, a dessacralizaçáo da sociedade, que tinha nos deuses, em seguida na Igreja e depois no rei suas bases axiológicas, deixa um vazio que a autora denomina de "sociedade órfā", pois, conforme já esclarecido, na fase adulta, o superego instala-se nas instituiçóes, criando um sentimento de filho da Igreja, súdito do rei, filho da nação e, hoje, "filho da justiça".

Para a autora, o fenômeno foi confirmado na Alemanha, esclarecendo que

[...] não se trata simplesmente da ampliação objetiva das funções do Judiciário, com o aumento do poder da interpretação, ou a crescente disposiçấo para litigar ou, em especial, a consolidação do controle jurisdicional sobre o legislador, Mas, acompanha uma evoluçáo de representaçáo da Justiça por parte da populaçáo que ganha contornos de veneraçáo religiosa (MAUS, 2000, p. 185 - grifo nosso).

É neste contexto de inevitabilidade que Maus (2000, p. 192) atribui ao Tribunal Constitucional alemão o exercício da "teologia constitucional”. Dessa afirmativa, pode-se extrair a compreensão de que o brocardo popular presente no mundo jurídico de que "o juiz é deus" tem a seu favor o amparo científico na Psicologia freudiana, pois, efetivamente, a "sociedade órfâ" assim sacralizou o Poder Judiciário.

Na própria Alemanha, o Tribunal Constitucional Federal tem recebido duras críticas em sua metodologia de trabalho, pois o princípio da proporcionalidade possibilita verdadeiro decisionismo judicial (OMMATI, 2012, p. 27). E, no Brasil, como anteriormente 
apresentado, de igual forma, muitos estudiosos mostraram suas preocupaçóes e apresentaram suas críticas. Deles destacamos o alerta, em 2005, de Alexandre Bahia:

Deve-se refletir em que medida as críticas de Ingeborg Maus à Corte Constitucional alemã acima expostas podem ser aplicadas ao Supremo Tribunal Federal, notadamente a partir do momento em que, por exemplo, este se considera uma Corte Constitucional nos moldes europeus (ou ao menos num processo nesse sentido). Se entendemos que a solução para nossa (?) "Crise do Judiciário" se dará com a concentraçấo de competências nas mãos dos tribunais superiores - basta vermos a Emenda Constitucional de Reforma do Judiciário —-,sobre a aplicação das criticas de Ingeborg Maus ao nosso Judiciário e à aplicaçáo irrestrita do princípio da proporcionalidade como panacéia para resoluçáo de nossos conflitos entre direitos fundamentais - principalmente porque isso implica referência a uma ordem suprapositiva de valores, confundindo direitos, normas morais, políticas, argumentos de custo/benefício etc (p. 12).

Como anota Habermas (2003, p. 330), “[...] no discurso sobre a divisão de trabalho entre tribunal constitucional e legislador democrático, os espíritos se dividem" e "[...] se, por um lado, a democracia exige que as decisóes políticas sejam tomadas por representantes escolhidos pelo povo, por outro, convive com o controle judicial de constitucionalidade feito por um órgão não eleito" (PEDRA, 2012, p. 204), exigindo maior democratização dos canais de participação popular na função judiciária.

Somente uma sociedade livre e aberta de intérpretes da Constituição - atraindo a lição de Peter Häberle - talvez seja capaz de seduzir o superego para a "massa dos cidadãos" e convertê-los em legitimados do processo hermenêutico, pois, como retrata Cittadino (2000, p. 209), “[...] quando os cidadãos veem a si próprios não apenas destinatários, mas também como autores do seu direito, eles se reconhecem como membros livres e iguais de uma comunidade jurídica”.

\section{Conclusões}

A Constituição da República Federativa do Brasil dispóe em primeiro artigo, mais precisamente no parágrafo único, que o "Poder emana do povo, que o exerce por meio de representantes eleitos ou diretamente".

Como estudado, mirando a estrutura freudiana do indivíduo, haverá sempre uma instituição, escolhida pelo povo, que funcionará como receptáculo do "superego da sociedade", aquela em que ele deposita sua fé e sua crença.

Sob esta compreensão, destaca-se que, no novo paradigma do Estado Democrático de Direito, a sociedade elegeu o Poder Judiciário, ainda que de maneira inconsciente, para atuar como o seu "censor moral" e erigir os superegos dos indivíduos dessa mesma 
sociedade. Inevitável, como outrora foi para a Igreja, para os Reis, para o Poder Legislativo no Estado de Direito, para o Poder Executivo no Estado Social. Cada um, no seu tempo, foi receptáculo do "superego da sociedade".

De igual forma o foi (e continua sendo) na Alemanha de Maus de 1989 ou no Brasil dos brasileiros dos tempos atuais. E, no mesmo movimento, no mesmo giro, após um processo constituinte e a instauração de um novo Estado (na Alemanha, como também no Brasil), observa-se a expansão da independência e "superiorização" do Poder Judiciário e de seus juízes em relação às outras instituições sociais, principalmente entre os poderes do Estado. O Estado Democrático de Direito e a adoção da "jurisprudência de valores" traz consigo, então, uma visão messiânica do Judiciário, ou seja, um "superapoderamento" do Poder Judiciário.

Nesse contexto, esta compreensão axiológica dos princípios revelada pela nova tendência argumentativa adotada pelo STF não se apresenta como a melhor alternativa em justificação contrária ao positivismo, pois o Estado desequilibra quando um Poder predomina sobre o outro, quando um Poder for capaz de "usurpar" o próprio Poder originário.

Essa é a crítica de Ingeborg Maus. A adoção da “jurisprudência de valores” como instrumento de definiçấo de denodos de toda uma sociedade infantiliza-a e faz com que permaneça irreflexa. O Judiciário não deixará espaço para a sociedade crescer ao retirar desta o poder de reflexão. Com a usurpação da compreensão de todos os valores de uma sociedade, não haverá mais espaço que não seja jurídico, já que tudo será julgado sob o aspecto axiológico. E assim tudo será determinado pelo Poder Judiciário, por exemplo, quem pode casar e com quem, ainda que a lei estabeleça expressamente o contrário.

E, mais ainda, quando o Poder Judiciário se arvora, como o fez o Tribunal Constitucional alemão, a reconhecer "[...] a existência de direitos suprapositivos que também vinculam o legislador constitucional, e se declara competente nestes termos para controlar o teor de constitucionalidade do direito vigente", ${ }^{6}$ assim não mais derivando a competência da Constituição, mas de "princípios de direitos suprapositivos" (MAUS, 2000, p. 191), o Poder Judiciário coloca-se numa instância que, parodiando os espanhóis ao referir-se à sua Capital, por encima sólo el cielo.

\section{Referências}

ALEXY, Robert. Derecho y razón práctica. México: Distribuiciones Fontamara, 1993.

. Teoria dos direitos fundamentais. 5. ed (1986). Tradução de Virgilio Afonso da Silva. São Paulo: Malheiros, 2006.

6 Citação de decisão do Repositório Oficial de Jurisprudência do TFC com grifo da Autora. 
BAHIA, Alexandre Gustavo Melo Franco. Ingeborg Maus e o Judiciário como superego da sociedade. CEJ, Brasília, n. 30, p. 10-12, jul./set. 2005.

CAPPELLETTI, Mauro. Juízes legisladores? Tradução de Carlos Alberto Álvaro de Oliveira. Porto Alegre: Fabris, 1993.

CARVALHO NETTO, Menelick de. Requisitos pragmáticos da interpretação jurídica sobre o paradigma do Estado Democrático de Direito. Revista de Direito Comparado, Belo Horizonte: Mandamentos vol. 03, 2000.

CATTONI DE OLIVEIRA, Marcelo Andrade. Jurisdição e hermenêutica constitucional no Estado Democrático de Direito: um ensaio da teoria da interpretação enquanto teoria discursiva da argumentação jurídica de aplicação. In: CATTONI DE OLIVEIRA, Marcelo Andrade (Org.). Jurisdição e hermenêutica constitucional. Belo Horizonte: Mandamentos, 2004.

. O caso Ellwanger: uma crítica à ponderação dos valores na jurisprudência recente do Supremo Tribunal Federal. 2005. Disponível em: <http://www.leniostreck. com.br> Acesso em: 21 set. 2005.

CHAUÍ, Marilena. Brasil: mito fundador e sociedade autoritária. 4. ed. São Paulo: Fund. Perseu Abramo, 2001.

CITTADINO, Gisele. Pluralismo, direito e justiça distributiva: elementos da filosofia constitucional contemporânea. 2. ed. Rio de Janeiro: Lumen Juris, 2000.

COURA, Alexandre de Castro. Hermenêutica jurídica e jurisdiçáo (in)consitucional: para análise crítica da "jurisprudência de valores" à luz da teoria discursiva de Habermas. Belo Horizonte: Mandamentos, 2009.

CRUZ, Álvaro Ricardo de Souza. Habermas e o direito brasileiro. Rio de Janeiro: Lumen Juris, 2008.

DWORKIN, Ronald. Levando os direitos a sério. 2. ed. Tradução de Nelson Boeira. São Paulo: Martins Fontes, 2007.

FREUD, Sigmund. Totem e tabu. Edição standard brasileira das obras psicológicas completas de Sigmund Freud. Rio de Janeiro: Imago, 1913-1996a. v. XIII, p. 13-168.

. O futuro de uma ilusáo. Edição standard brasileira das obras psicológicas completas de Sigmund Freud. Rio de Janeiro: Imago, 1927-1996b, v. XXI, p. 15-66.

Novas conferências introdutórias à psicanálise. Conferência XXXI: A dissecção da personalidade psíquica. Edição standard brasileira das obras psicológicas completas de Sigmund Freud. Rio de Janeiro: Imago, 1932-1996c, v. XXII, p. 3954.

Moisés e o monoteísmo. Três ensaios (1939 [1934-38]). Rio de Janeiro: Imago, 1975. 
GARAPON, Antoine. O juiz e a democracia: o guardião de promessas. Tradução de Maria Luíza de Carvalho. 2. ed. Rio de Janeiro: Revan, 2001.

HÄBERLE, Peter. Hermenêutica constitucional: a sociedade aberta dos intérpretes da constituição: contribuição para a interpretação pluralista e "procedimental" da Constituição. Porto Alegre: Sergio Antônio Fabris, 1997.

HABERMAS, Jürgen. Direito e democracia: entre facticidade e validade. Tradução de Flávio Beno Siebeneichler. 2. ed. Rio de Janeiro: Tempo Brasileiro, 2003, v. 1 e 2.

MAUS, Ingeborg. Judiciário como superego da sociedade: o papel da atividade jurisprudencial na "sociedade órfâ". Tradução de Martônio Lima e Paulo Albuquerque. Novos Estudos CEBRAP, São Paulo, n. 58, p. 183-202, nov. 2000.

OMMATI, José Emílio Medauar. Liberdade de expressão e discurso do ódio na Constituiçáo de 1988. Rio de Janeiro: Melhoramentos, 2012.

PEDRA, Adriano Sant'Ana. A Constituição viva: poder constituinte permanente e cláusulas pétreas na democracia participativa. 2. ed. Rio de Janeiro: Lumen Juris, 2012.

STRECK, Lenio Luiz; BARRETO, Vicente de Paulo; OLIVEIRA, Marcelo Andrade Cattoni de. Ulisses e o canto das sereias: sobre ativismos judiciais e os perigos da instauração de um "terceiro turno da constituinte". Revista de Estudos Constitucionais, Hermenêutica e Teoria do Direito. Rio Grande do Sul, n 1 (2), p. 75-83, jul./dez. 2009. 